\title{
ЗМІСТ І СУТНІСТЬ САМОСТІЙНОЇ НАВЧАЛЬНОЇ ДІЯЛЬНОСТІ УЧНІВ СТАРШӦ̈ ШКОЛИ
}

\begin{abstract}
Автор ставить завдання з'ясувати зміст і сутність понять «самостійна навчальна діяльність учнів старшої школи», «організачія самостійної навчальної діяльності учнів старшої иколи», «самостійна робота учнів старшої школи».

Ключові слова: самостійна навчальна діяльність, організація самостійної навчальної діяльності, самостійна робота.

Автор ставит задачу определить суть и содержание понятий «самостоятельная учебная деятельность учащихся старией школьl», «организачия самостоятельной учебной деятельности учащихся старшей школы», «самостоятельная работа учашихся старшей школьрџ.

Ключевые слова: самостоятельная учебная деятельность, организация самостоятельной учебной деятельности, самостоятельная работа.
\end{abstract}

The author posits the problem of defining the content and the essence of the notions «high-school pupils' independent educational activity», «organizing high-school pupils' independent educational activity», and «self-directed work».

Kew words: independent educational activity, organizing independent educational activity, self-directed work.

Однією $з$ актуальних проблем сучасної педагогічної науки є підвищення рівня ефективності організації самостійної навчальної діяльності учнів старшої школи. Орієнтиром для вчителів має бути старшокласник, адаптований до навчально-виховного процесу, який володіє вміннями та навичками самостійної навчальної діяльності, здатний швидко та творчо розв'язувати будь-які завдання, готовий до самоосвіти, саморозвитку, самовдосконалення.

Згідно з Державним стандартом базової і повної середньої освіти, одним із завдань освітньої галузі у старшій школі $є$ вдосконалення вмінь і навичок самостійної навчальної діяльності, розвиток інтелектуальних, творчих здібностей учнів. У Національній доктрині розвитку України у XXI ст. визначено перспективні завдання розвитку змісту освіти, особливості вдосконалення навчальновиховного процесу в загальноосвітніх навчальних закладах, підвищення рівня сформованості пізнавальної самостійності й активності учнів старшої школи у навчанні [1]. Максимально підготовлений до самостійної навчальної діяльності випускник школи - це успішний у майбутньому студент вищого навчального закладу.

Очевидним є зв'язок проблеми з практичними завданнями як середньої так і вищої школи, успішне розв'язання якої сприятиме оптимальній адаптації випускника школи до специфіки навчання у вищому навчальному закладі, до розвитку особистісних характеристик учнівської та студентської молоді.

Важливою подією у вітчизняній освіті, на думку багатьох науковців, стало впровадження зовнішнього незалежного оцінювання навчальних досягнень осіб, які мають бажання вступати до вищих навчальних закладів. Вступ до вищого навчального закладу є однією з найголовніших подій у житті молодої людини, оскільки під час вступних випробувань необхідно довести, що рівень знань, здобутих упродовж шкільних років, відповідає вимогам початкового етапу навчання у вищий школі.

Процедура тестування, насамперед, виключає суб'єктивний чинник, забезпечує рівність, відкритість, прозорість, об'єктивність результатів, що сприяє усвідомленню учнями старшої школи необхідності докладання зусиль до самостійного оволодіння знаннями (в аудиторії тестування абітурієнту ніхто не допоможе, тільки він сам повинен виконати завдання, тільки від нього залежить скільки балів набере й відповідно наскільки впевнено він буде конкурувати 3 іншими - отже, запорукою успіху постають міцні знання, розвинуті навчальні (у тому числі й самостійної навчальної діяльності) уміння й навички, психологічна готовність - усе це, результат передовсім самостійної навчальної діяльності, власних зусиль для досягнення мети. Ураховуючи власний педагогічний досвід, можемо констатувати, що учні старшої школи загальноосвітніх навчальних закладів недостатньо володіють навичками самостійної навчальної діяльності.

Тому одним із завдань, яке постає перед середньою освітою $є$ формування вмінь і навичок самостійної навчальної діяльності протягом навчання в школі, і зокрема, в старших класах.

За результатами аналізу останніх досліджень і публікацій робимо висновок, що проблема підвищення рівня самостійної навчальної діяльності учнівської та студентської молоді привертає увагу авторитетних науковців- педагогів, психологів. Проблему підготовки дитини до самостійної діяльності під час перебування в школі досліджували Н. Бороздінов, Є. Голант, Б. Єсіпов та ін.). Починаючи 3 другої половини XX ст. провідними педагогами одним із недоліків загальноосвітньої школи визначено недостатню підготовленість випускників шкіл до самостійного набуття знань.

Дослідженням організаційного аспекту самостійної роботи: учнів загальноосвітніх навчальних закладів опікувалися такі дидакти: Н. Дайрі, В. Краєвський, І. Лернер, М. Скаткін, В. Сластьонін; студентів вищих навчальних закладів - Я. Болюбаш, В. Буряк, І. Зязюн, Л. Кондрашова, В. Кремень, О. Малихін та ін. Висновки науковців доводять: регулярно й правильно застосовувана самостійна 
робота розвиває довільну увагу дітей, відпрацьовує здатність до міркування, ана-лізу, самостійного прийняття рішення, де найчастіше виявляється мотивація учнів, цілеспрямованість, самоорганізованість, самостійність та інші особистісні характеристики.

Mета статmi: виявити зміст і сутність понять «самостійна навчальна діяльність учнів старшої школи», «організація самостійної навчальної діяльності учнів старшої школи», «самостійна робота учнів старшої школи».

Організація навчальної діяльності учнів старшої школи передбачає включення поряд 3 урочною формою навчання позаурочної діяльності, позашкільної зайнятості, загальної самостійної діяльності причому за різними напрямками. Термін «навчання», за редакцією В. Бондаря, означає «привласнення соціального досвіду суб'єктом освіти як в умовах самовключення в навчальну діяльність, так й організовану вчителем» [2, с. 76].

Самостійна навчальна діяльність учня є найбільш бажаним наслідком правильно організованої роботи на уроках, яка мотивує самостійне розширення, поглиблення й продовження у вільний час. Самостійна навчальна діяльність учня - ширше поняття, ніж просто домашня робота, яка полягає у виконанні домашніх завдань, повинна розглядатися вчителем як самостійна, вища форма навчальної діяльності учнів, без засвоєння якої неможливо досягти кінцевої мети навчання в школі тобто, закласти, виховати в учнів навички до самоосвіти та самовдосконалення.

Самостійна навчальна діяльність повинна бути усвідомлена учнем як вільна за вибором внутрішньо мотивована діяльність. Вона передбачає виконання низки таких дій: усвідомлення мети діяльності, визначення особистісного значення навчальних завдань, підпорядкування їх вирішенню інших інтересів і форм зайнятості, самоорганізацію в розподілі навчальних дій у часі, самоконтроль тощо. Істинно самостійна навчальна діяльність учня можлива тоді, коли в учня виникає потреба засвоєння нового, невідомого, важливого.

У зв'язку 3 цим самостійна робота учнів набуває більш важливого значення як основна організаційна форма здійснення самостійної навчальної діяльності учнівської молоді. Цій проблемі протягом тривалого часу приділяється увага в літературі 3 педагогіки, психології й методики викладання окремих предметів. Можна сказати, що тема самостійної роботи учнів $є$ однією 3 найважливіших і широко обговорюваних проблем навчання в середній школі.

Аналіз наукової літератури дозволив авторові окреслити основні підходи до визначення поняття «самостійна робота». Відтак у педагогічній літературі напрапляємо на різні тлумачення окресленого поняття, які можна згрупувати за такими аспектами: 1) різноманітні види індивідуальної та групової пізнавальної діяльності учнів чи студентів, які здійснюються в урочний (аудиторний) чи в позаурочний (позааудиторний) час (Р. Нізамов, Н. Сагіна та ін.); 2) різноманітні типи навчальних завдань, які виконуються під керівництвом учителя чи викладача (М. Гарунов, Л. Зоріна, Н. Нікандров, П. Підкасистий, М. Скаткін та ін.); 3) система організації роботи, за якої управління навчальною діяльністю учнів чи студентів відбувається за відсутності вчителя або викладача (В. Граф, І. Іллясов, В. Ляудіс, Н. Сагіна, О. Чиж та ін.); 4) робота учнів чи студентів, яка проводиться за спеціальним індивідуальним навчальним планом, складеним на основі врахування індивідуальних особливостей i пізнавальних можливостей учнів чи студентів (С. Архангельський, Л.Деркач, Н. Сагіна, І. Шайдур та ін.); 5) різновид діяльності учнів, за якого в умовах систематичного зменшення прямої допомоги вчителя виконуються навчальні завдання, що сприяють свідомому й міцному засвоєнню знань, умінь i навичок формування пізнавальної самостійності як риси особистості учня (Л. Вяткін).

Таким чином, змістовий аналіз наукових підходів, присвячених проблемі навчання самостійної роботи в загальноосвітніх навчальних закладах, дозволяє сформулювати такі ключові положення:

- самостійна робота визначається більшістю дослідників як різновид пізнавальної діяльності учнів на уроці та вдома; виконання якої здійснюється за завданням учителя, але без його безпосередньої участі. Автор поділяє думку Н. Зеленкової щодо того, що пізнавальна діяльність - «це готовність до самостійного оволодіння знаннями на основі вольового зусилля. Як складна особистісна якість поєднує у структурі знання, мотиви, способи дій, рівень вираження яких має значний вплив на характер і результати навчальної діяльності» [3, с. 31];

- самостійна робота сприяє формуванню таких важливих рис особистості, як: самостійність, самоорганізованість, цілеспрямованість, пізнавальна активність, творче ставлення до праці тощо;

- самостійна робота передбачає усвідомлення кожного завдання, тобто у процесі виконання завдань самостійної роботи учні використовують знання, предметні вміння, досвід під час вивчення дисципліни, а також уміння користуватись засобами навчання;

- $\quad$ самостійна робота вимагає володіння учнями певними загальними навчальними уміннями, що сприяють раціональній організації.

Як зазначає О. Малихін, «самостійна робота як дидактична форма навчання є системою організації педагогічних умов, що забезпечує управління навчальною діяльністю тих, хто навчається, відбувається за відсутності викладача й без його безпосередньої участі й допомоги. Під час виконання самостійної роботи підтримка викладача реалізується опосередковано через організацію системи навчання в умовах самопідготовки. У цьому полягає дидактична сутність самостійної роботи 
й відміність від інших форм» [6, с. 38].

Будучи особливою, вищою формою навчальної діяльності, самостійна робота зумовлюється індивідуально-психологічними та особистісними особливостями учня як суб'єкта діяльності. Він повинен мати цілісне уявлення про власні можливості й уміти їх реалізувати. Школяр (особливо, коли йдеться про старшу школу) має не тільки розуміти запропоновані вчителем цілі, але й уміти формувати їх самостійно, моделювати власну діяльність, обираючи умови, важливі для досягнення мети; програмувати самостійну діяльність, добираючи адекватні засоби; визначати послідовність окремих дій, оцінюючи проміжні та кінцеві результати діяльності; коригувати свої дії. Це грунтується на сформованих в учнів знаннях, уміннях $\mathrm{i}$ навичках в основній навчальній діяльності під керівництвом учителя.

Отже, із позиції суб'єкта діяльності самостійна робота може бути визначеною як цілеспрямована, внутрішньо мотивована, структурована і коригована суб'єктом діяльності; виконання якої вимагає достатньо високого рівня самосвідомості, рефлективності, самодисципліни, особистої відповідальності й надає учневі задоволення як процес самопізнання й самовдосконалення.

Вибір предмета самостійних занять визначається індивідуальними інтересами, здібностями, конкретною ситуацією, умовами життя, підтримкою батьків, тощо. Завдання вчителя - тактовно формувати індивідуальні інтереси та прагнення. Індивідуальні захоплення - найрізноманітніші. Однак, долучити учня до світу пізнання нового, допомогти розвинутися дитині так, щоб вона могла й хотіла здобувати знання (а не одержати їх), могла набувати вміння й навички $є$ важливим завданням педагогів.

Пам’ятаємо, що найкращий учитель той, хто збуджує в учнів бажання вчитися. Ця незаперечна істина проголошувалася в тій чи тій формі прогресивними педагогами всіх часів. В. Сухомлинський, звертаючись до вчителів, писав: «Не забувайте, що грунт, на якому будується ваша педагогічна майстерність, - у самій дитині, у її ставленні до знань і до вас, учителю. Це - бажання вчитися, натхнення, готовність до подолання труднощів. Дбайливо збагачуйте цей грунт, без нього немає школи» [8]. Щоб навчити дитину, треба не просто передати їй знання й уміння, а й викликати в неї відповідну активність, самостійність, творчість.

Якщо немає потягу й любові до навчання, до самовдосконалення протягом усього життя, то безперервна освіта неможлива. Елементи самоосвіти, у широкому розумінні цього слова, закладаються в шкільні роки. В українській педагогічній спадщині перу Софії Русової належать слова: «Треба не вчити дитину, не давати їй готове знання, хоч би й саме початкове, а більш усього збудити в дитині її духовні сили, розворушити цікавість, виховати їі почуття, - щоб очі дитини вміли бачити, вуха дослухатися до всього, рученята вміли заходжуватися й коло олівців, і коло ножиць, $\mathrm{i}$ коло глини, й коло паперу» [5, с. 319].

Аналіз досвіду роботи дозволяє стверджувати, що старшокласники краще готуються до уроків тих учителів, з якими встановлено дружні відносини, авторитет яких $є$ високим, предмети яких необхідні для вступу у вищий навчальний заклад. Водночас повна гармонія між учителем й учнем виникає за певних умов, насамперед, коли, по-перше, учитель працює над своїм розвитком і вдосконаленням; по-друге, діяльність учителя забезпечує самореалізацію, самоствердження, самовдосконалення, соціалізацію особистості учня; по-третє, учитель добре володіє прийомами спілкування з підлітками періоду юнацтва, не припускається принижень, образ, є носієм високих моральних якостей.

Учнівська молодь щодо життєвих ціннісних орієнтацій є досить гострою й неоднозначною. Питання впливу прикладу на особистість набуває великого теоретичного і практичного значення. Нині родинні стосунки у переважній більшості слабшають, зв'язок батьків зі школою також - і це, у свою чергу, призводить до втрати у багатьох молодих людей поваги до авторитету батьків і вчителів. А для успішного навчання й у школі, й у виші батьківська підтримка є необхідною.

Складність праці вчителя в даному напрямку полягає в тому, щоб знайти підхід до кожного учня, створити умови для розвитку здібностей, закладених у кожному, спонукати до самостійної навчальної діяльності. У цьому сенсі успішний перехід випускника школи до ролі студента вищого навчального закладу без наявних сформованих умінь і навичок самостійної навчальної діяльності неможливий.

Отже, поняття «самостійна навчальна діяльність учнів старшої школи», «організація самостійної навчальної діяльності учнів старшої школи», «самостійна робота учнів старшої школи» - це складні багатомірні педагогічні явища, що охоплюють систему взаємопоєднаних структурних i функціональних компонентів, утворюють цілісну єдність, підпорядковану цілям виховання, освіти й розвитку в умовах опосередкованого управління й самоуправління.

Слід наголосити, що дані поняття не $є$ тотожніми: самостійна робота $€$ лише складовою самостійної навчальної діяльності, її основною формою реалізації. Поняття «організація самостійної навчальної діяльності» окреслює організаційні форми самостійної навчальної діяльності, такі як самостійна робота, консультація, практична робота, лабораторна робота, науково-дослідницька діяльність тощо. 
Перспективою подальших досліджень у цьому напрямку є створення окремої програми спецкурсу «Основи самостійної навчальної діяльності» для учнів 10-11-х класів загальноосвітніх навчальних закладів та апробування в школі.

\section{Література}

1. Національна доктрина розвитку України у XXI столітті // Освіта України. - 2001. - № 29. 2. Бондар В. I. Дидактика / Віктор Іванович Бондар. - К., 2005. - 262 с. 3. Зеленкова Н. Формування пізнавальної самостійності старшокласників у навчальному процесі / Н. Зеленкова // Рідна школа. - 2005. - № 8. - С. 31-33. 4. Кузьмінський А. І. Педагогіка / А. І. Кузьмінський , В. Л. Омеляненко. - К., 2007. - 447 с. 5. Любар О. О. Історія української школи і педагогіки / О. О. Любар, М. Г. Стельмахович, Д. Т. Федоренко. - К., 2006. - С. 315-321. 6. Малихін О. В. Організація самостійної навчальної діяльності студентів вищих педагогічних навчальних закладів: теоретико-методологічний аспект / Олександр Володимирович Малихін. - Кривий Ріг : «Видавничий дім», 2009. - 306 с. 7. Пидкасистый П. И. Самостоятельная деятельность учащихся / Павел Иванович Пидкасистый. - М. : Педагогика, 1972. - 182 с. 8. Сухомлинський В. О. Серце віддаю дітям/ Василь Олександрович Сухомлинський. - К., 1972. - 243 с. 9. Терепищий С. О. Сучасна освіта - це інноваційність / С. О. Терепищий // Освіта України. - 2011. - №8. - С. 5. 